\title{
STRUKTURNE SPREMEMBE V SLOVENSKEM KMETIJSTVU IN RAZVOJ PODEŽELJA
}

Tomaž Cunder*

\section{IZVLEČEK}

Temeljna značilnost slovenskega kmetijstva je, da se je dolgo časa razvijalo $v$ povsem drugačni smeri kot kmetijstvo $v$ EU, kar še posebej velja za agrarno strukturo. Medtem ko se je $v$ državah $z$ razvitim kmetijstvom razmeroma hitro povečevala velikost obratov in vzporedno z izboljševanjem kmetijske tehnologije specializacija pridelave, pa se je vse do začetka devetdesetih let 20. stoletja (predvsem v zasebnem sektorju slovenskega kmetijstva) odvijal ravno obraten proces. Evidentno je bilo nenehno slabšanje zemljiške in posestne strukture, nizka delovna intenzivnost in $v$ nekaterih območjih tudi opuščanje pridelave. Trdimo lahko, da se je v slovenskem kmetijstvu nenehno poglabljala protislovnost med družbenoekonomsko strukturo kmečkega prebivalstva in agrarno strukturo. Posledice se kažejo v tem, da imamo z vidika deleža kmečkega prebivalstva v Sloveniji že socialno in demografsko strukturo razvite družbe, medtem ko agrarna struktura še vedno izkazuje značilnosti klasične agrarne družbe.

Ključne besede: raba zemljišč, kmetijstvo, struktura kmetijskih gospodarstev, podeželje, Slovenija.

\section{STRUCTURAL CHANGES IN SLOVENIAN AGRI- CULTURE AND RURAL DEVELOPMENT}

\section{Abstract}

The basic characteristic of Slovene agriculture is the fact that for a long time it has been developing in a totally different direction from the EU agriculture. This is especially true in the case of agrarian structure and its development. While in the countries with developed agriculture, together with the improvement of agricultural technology the process of enlarge-

\footnotetext{
* Tomaz Cunder, dipl. geolog, Kmetijski inštitut Slovenije, Haequetova? , SI-1000 Ljubljana, epošta: tomaz.cunder
} 
ment of farms and concentration and specialisation of production were going on relatively fast, the private sector of Slovene agriculture until the 1990s was characterised by permanent decrease and fragmentation of the land property, by low working intensity of production and, in some areas, by gradual abandoning of production. It can be maintained that in Slovene agriculture the discrepancy between social-economic structure of rural population and agrarian structure has become deeper. Evident processes resulted in a fact that Slovenia has a demographic structure of developed society (from the viewpoint of share of rural population), but, with regard to agrarian structure, it has the characteristics of a classical agrarian society.

Key words: land use, agriculture, structure of agricultural holdings, rural areas, Slovenija. 


\section{Uvod}

V nasprotju z večino razvitih zahodnoevropskih držav, za katere je značilna visoka stopnja razvoja kmetijske tehnologije, Slovenija zaradi specifičnega zgodovinskega razvoja in z njim podedovane slabe agrarne strukture, še vedno sodi $v$ krog tistih držav, ki $z$ razvojem modernega, proizvodno in delovno učinkovitega kmetijstva praktično šele pričenjajo. Čeprav je slovensko kmetijstvo zaradi naravnih razmer prisiljeno gospodariti v težjih pridelovalnih razmerah, so predvsem zelo slaba velikostna in posestna struktura kmetij, nizka stopnja profesionalizacije ter še vedno razmeroma nizka delovna intenzivnost tisti dejavniki, ki odločilno zavirajo hitrejše prilagajanje naših proizvodnih struktur evropskim.

Slovenija se kljub morebitnemu pristopu k Evropski Uniji ne more in ne sme odreči lastnemu kmetijstvu. Kot dejavnost, ki zagotavlja tako prehransko varnost prebivalstva kot tudi ohranjanje poseljenosti in obdelanosti kulturne pokrajine, še vedno predstavlja enega od temeljev politične in gospodarske suverenosti naroda in države. Strateški pomen lastne pridelave hrane in doseganja čim višje stopnje samooskrbe je glede na zgodovinske izkušnje še posebej pomembno za manjše države, med katere tako z ozemeljskega kot tudi demografskega vidika vsekakor sodi tudi Slovenija.

\section{Temeljne značilnosti kmetijstva v Sloveniji}

\section{Raba zemljišč}

Kakšen je prostorski položaj in pomen kmetijstva v Sloveniji, je najbolj razvidno iz strukture rabe zemljišč. V tem pogledu Slovenija v veliki meri odstopa od evropskega povprečja. To še posebej velja za srednjeevropski prostor, kjer ni države, ki bi razpolagala s tako velikim deležem gozda $v$ strukturi rabe zemljišč. Medtem ko v EU gozd v povprečju pokriva le tretjino zemljišč, pa je v Sloveniji ta delež že konec osemdesetih let 20. stoletja presegel polovico in po zadnjih podatkih že presega tudi $60 \%$.

Značilna posledica specifičnih naravnih razmer za kmetijsko pridelavo $v$ Sloveniji je tudi velik delež absolutnega travinja (travnikov in pašnikov) in nasprotno razmeroma majhen delež njiv in trajnih nasadov (sadovnjakov in vinogradov) v strukturi rabe kmetijske zemlje. 
Slovenija razen ravninskega dela subpanonskega sveta na severovzhodu ter nekaterih sklenjenih območij $v$ dnu kotlin in ravnin, nima pomembnejših območij, primernih za intenzivno poljedelsko pridelavo. Njivski svet je omejen na razmeroma majhne površine, ki pa so še dodatno ogrožene s strani urbanizacije. Razen Irske v EU ni države, ki bi imela manjši delež njiv v strukturi rabe kmetijske zemlje, kot ga ima Slovenija. Z 0,08 ha njiv na prebivalca daleč zaostajamo za povprečjem EU in imamo v povprečju 3-krat manj njiv na prebivalca kot večina drugih držav, kandidatk za vstop v EU.

Travinje v slovenskem kmetijstvu absolutno prevladuje, saj zavzema več kot dve tretjini kmetijskih zemljišč (dvakratno povprečje EU, kjer ima večji delež travinja v strukturi rabe le še Irska). Za travinje v Sloveniji je značilno, da je praviloma slabo izkoriščeno: dobri dve tretjini travnatega sveta se koristi $v$ obliki travnikov, slaba tretjina pa v obliki ekstenzivnih pašnikov.

Zaradi geografske lege, ki je deloma submediteranska in deloma subpanonska, je delež kmetijskih zemljišč, primernih za trajne nasade, v Sloveniji razmeroma velik. Na prebivalca ima Slovenija enako površino trajnih nasadov kot EU, kjer pa k temu največ prispevajo Grčija, Italija, Španija in Portugalska. $V$ teh državah trajni nasadi v strukturi rabe zemljišč predstavljajo med 15 in $20 \%$.

Grafikon 1 : Struktura rabe kmetijske zemlje v Sloveniji in državah EU (\%).

Fig.1: Agricultural land use structure in Slovenia and EU countries (\%).

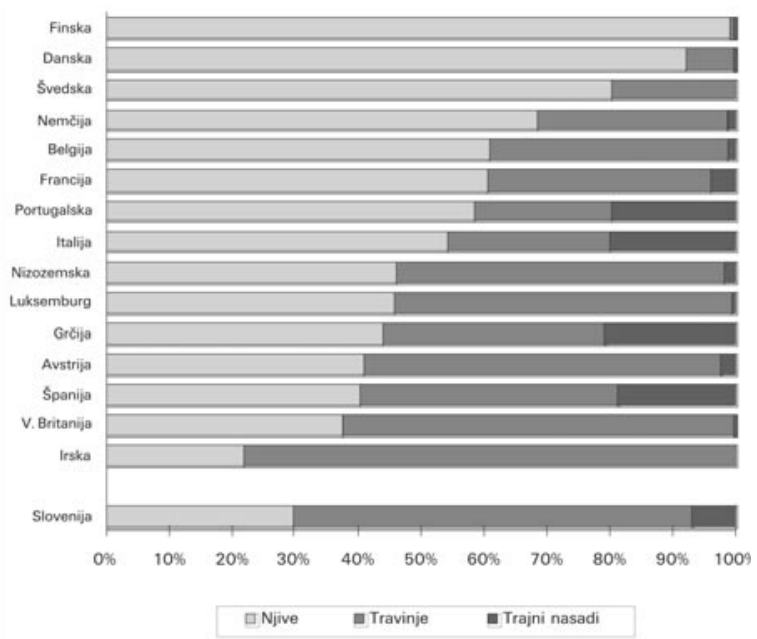

Vir/Source: 


\section{Naravne razmere za kmetijsko pridelavo}

Zaradi izrazite reliefne razčlenjenosti Slovenija prav gotovo ne spada med države z ugodnimi naravnimi danostmi za kmetovanje. Nasprotno, v evropskem merilu sodi Slovenija zaradi svoje razgibanosti in goratosti ter velikega deleža kraških območij v krog držav z najtežjimi pridelovalnimi razmerami. Čeprav način opredeljevanja območij z omejenimi dejavniki v Sloveniji in EU ni direktno primerljiv, lahko ugotovimo, da imajo znotraj EU samo Luksemburg, Portugalska, Finska in Grčija težje pridelovalne razmere. Če pa se omejimo zgolj na hribovska območja, se Slovenija uvršča celo na četrto mesto, takoj za Grčijo, Avstrijo in Finsko.

Slabše pridelovalne razmere sicer ne onemogočajo kmetijske pridelave, pač pa vplivajo na manjšo proizvodno sposobnost kmetij, manjši izbor kultur in proizvodnih usmeritev ter dražijo pridelavo. Hribovsko kmetijstvo je manj konkurenčno zaradi specifičnih naravnih razmer, ki se odražajo tudi v strukturi rabe kmetijske zemlje, pa tudi manj prilagodljivo in dražje.

Grafikon 2 : Kmetijska zemlja v območjih z omejenimi dejavniki za kmetijsko pridelavo.

Fig.2: Agricultural land in less favorued areas for agricultural production.

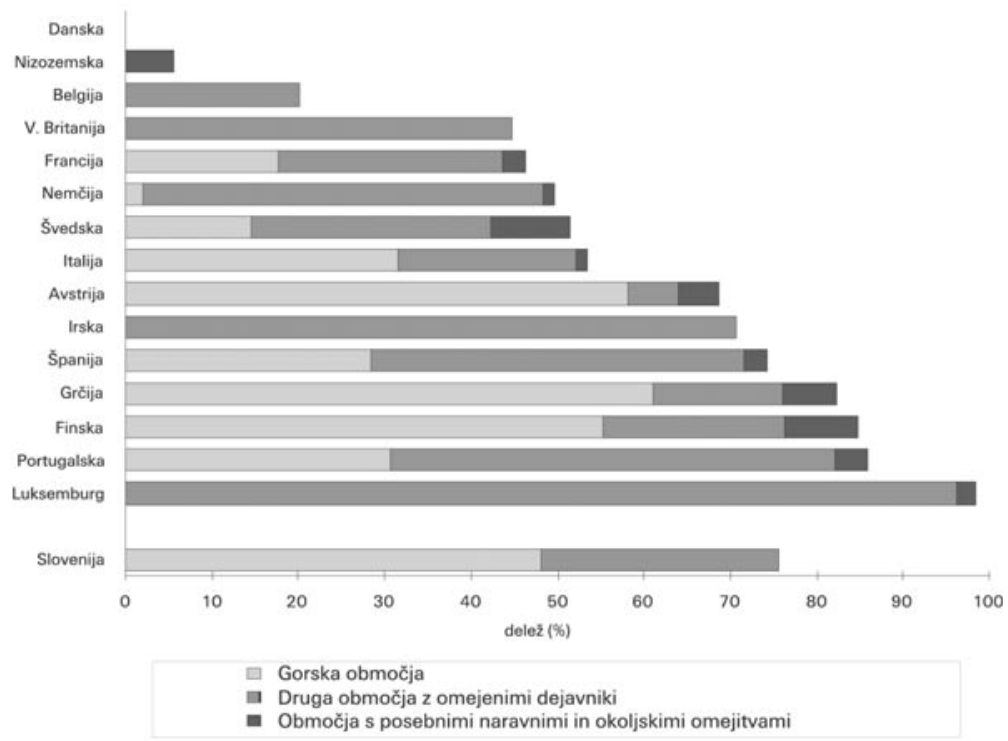

Vir/Source: 


\section{Pomen živinoreje}

Zaradi naravnih danosti predstavlja živinoreja osrednjo panogo $v$ slovenskem kmetijstvu. Kljub temu da delež živinoreje $v$ bruto vrednosti kmetijske pridelave tako $v$ Sloveniji kot tudi $v$ povprečju EU znaša več kot $50 \%$, pa je evropska živinoreja podvržena veliko manjšim nihanjem $v$ obsegu prireje kot slovenska. Medtem ko se je samo $v$ zadnjem desetletnem obdobju $v$ naši državi število živine, preračunane na glave velike živine (GVŽ), zmanjšalo za več kot $15 \%$, se je v istem obdobju število živine na ravni EU zmanjšalo samo za dobra $2 \%$.

Govedo še vedno predstavlja več kot 70 \% vse živine v Sloveniji. V EU imajo le Francija, Irska in Luksemburg $v$ strukturi živine več govedi kot naša država. Obratno razmerje se pojavlja pri prašičih, predvsem pa pri drobnici, kjer ima Slovenija (kljub ugodnim razmeram za rejo) v strukturi povsem zanemarljiv delež.

Preglednica 1 : Primerjava števila glav velike živine (GVŽ) v Sloveniji in EU.

Tab.1: The number of cattle (comparison Slovenia-EU).

\begin{tabular}{|l|c|c|}
\hline & Slovenija & EU-15 \\
\hline Število glav velike živine (GVŽ) v Sloveniji in EU & 479 & 115380 \\
\hline Struktura GV & & \\
- govedo & 76,7 & 52,3 \\
- prašič & 12,7 & 24,4 \\
- ostalo (drobnica, konji) & 10,6 & 23,3 \\
\hline Število GVŽ na ha kmetijske zemlje & 0,85 & 0,90 \\
\hline
\end{tabular}

Vir/Source: Statistični urad RS, EUROSTAT.

Intenzivnost živinorejske proizvodnje, merjene s številom GVŽ na ha kmetijske zemlje, se je $v$ Sloveniji $v$ zadnjem obdobju kljub absolutnemu zmanjšanju števila živine vseeno povečala. Seveda še zdaleč ne dosega ravni, kot jo dosegajo živinorejsko najbolj razvite države (Nizozemska, Belgija, Danska), vendar pa se je že $v$ veliki meri približala povprečju držav EU. Avstrija kot država, ki ima podobne pridelovalne razmere in kjer živinoreja zavzema podoben delež v kmetijski pridelavi, v povprečju dosega le okoli $40 \%$ višjo intenzivnost kot naša država. Število GVŽ na ha kmetijske zemlje pa je 
poleg merila, ki opredeljuje intenzivnost živinorejske proizvodnje tudi pomembno ekološko merilo. $\mathrm{V}$ tem pogledu ima kmetijstvo $\mathrm{v}$ nekaterih območjih Slovenije (hribovskih, gorskih, kraških) zaradi nizke obremenitve v smislu okolju prijaznega kmetovanja, veliko razvojno priložnost.

\section{Agrarna struktura}

Ob Popisu kmetijskih gospodarstev leta 2000 je bilo v Sloveniji nekaj več kot 86300 kmetijskih gospodarstev - kmetij. Po evropskih merilih standardne ekonomske moči (ESU), ki upoštevajo proizvodno sposobnost obratov, so te kmetije direktno primerljive z evropskimi.

\section{Velikostna struktura kmetij}

V primerjavi z večino držav EU so kmetije pri nas izjemno majhne. Če je bila še leta 1931 povprečna slovenska kmetija po površini povsem blizu povprečni srednjeevropski kmetiji, je danes glede na površino kmetijske zemlje kar petkrat manjša kot podoben obrat v EU. Kljub dejstvu, da smo izrazita živinorejska država, je razlika pri številu živine še večja, saj povprečna evropska kmetija redi kar šestkrat več GVŽ na kmetijo kot povprečna slovenska kmetija.

Grafikon 3 : Velikost kmetij v Sloveniji in EU glede na povprečno površino zemljišč in število živine.

Fig. 3: Avarage farm size in Slovenia and EU (land categories size, number of cattle).
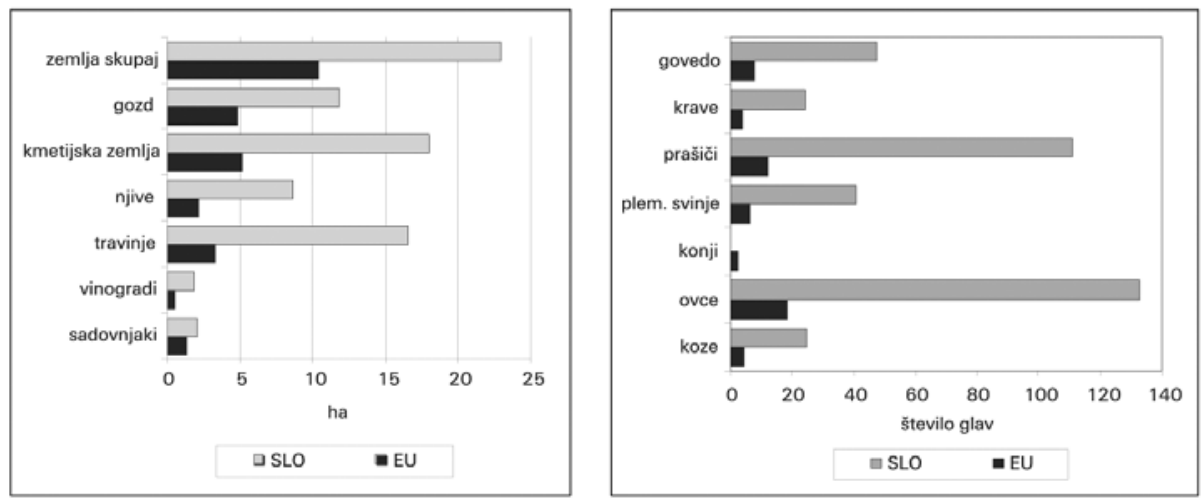

Vir/Source: 
Medtem ko se v medpopisnem obdobju 1981-1991 povprečna velikost slovenske kmetije (ocena na podlagi skupne zemlje) praktično ni spremenila, pa se je $v$ devetdesetih letih 20. stoletja vendarle pričelo obdobje zmerne koncentracije posesti in zemljišč. V obdobju med popisom prebivalstva 1991 in Popisom kmetijskih gospodarstev leta 2000 se je tako površina kmetijske zemlje $v$ uporabi na kmetijo povečala za 0,7 hektara ali za dobrih $15 \%$.

Tabela 2: Povprečna velikost kmetij (ha kmet. zemlje) v izbranih državah EU in Sloveniji.

Tab.2: Average farm size in EU countries and Slovenia (in ha of agricultural land).

\begin{tabular}{|l|c|c|c|c|c|}
\hline & 1987 & 1990 & 1993 & 1997 & $\begin{array}{c}\text { Indeks } \\
(1997 / 1987=100)\end{array}$ \\
\hline Zd. Kraljestvo & 63,7 & 67,1 & 67,3 & 70,1 & 110,1 \\
\hline Francija & 23,3 & 30,5 & 35,1 & 41,7 & 178,9 \\
\hline Nemčija & 14,4 & 26,1 & 28,1 & 32,1 & 223,0 \\
\hline Nizozemska & 13,7 & 16,1 & 16,8 & 18,6 & 136,0 \\
\hline Avstrija & 12,5 & 12,7 & 12,9 & 16,3 & 130,0 \\
\hline Portugalska & 4,3 & 6,7 & 8,1 & 9,2 & 213,3 \\
\hline Grčija & 3,6 & 4,0 & 4,3 & 4,5 & 123,9 \\
\hline EU - 15 & 12,4 & 14,0 & 16,4 & 18,1 & 145,6 \\
\hline Slovenija ${ }^{1}$ & - & 4,6 & & 5,3 & - \\
\hline $\begin{array}{l}\text { Vir: EUROSTAT. Statistični urad RS } \\
\text {-:no data avaliable/ ni razpoložljivih podatkov }\end{array}$ & & & \\
\hline
\end{tabular}

Velikostna struktura slovenskih kmetij je praktično neprimerljiva z velikostno strukturo kmetij v EU. Več kot polovica kmetij je manjših od 2 ha in skoraj $70 \%$ manjših od 5 ha. Te kmetije so skupaj s kmetijami velikostnega razreda od 6 do 10 ha, temelj kmetijske pridelave v Sloveniji in zavzemajo kar dve tretjini kmetijskega prostora v Sloveniji. Podobno drobno velikostno strukturo imajo v EU le Grčija, Italija in Portugalska, kjer pa je pridelava na manjših kmetijah bolj specializirana in usmerjena $v$ proizvodno intenzivne usmeritve (vrtnarstvo, vinogradništvo, sadjarstvo).

\footnotetext{
1 Podatke za leto 1991 (Popis prebivalstva) in 2000 (Popis kmetijskih gospodarstev)
} 
Poleg neugodne strukture je v Sloveniji velik problem tudi precejšnja razdrobljenost posesti. Zanimivo je, da se le-ta kljub različnim ukrepom za večjo zemljiško koncentracijo celo povečuje. Podatki zemljiškega katastra v Sloveniji namreč kažejo, da se na eni strani povprečna velikost parcele še vedno zmanjšuje, po drugi strani pa se povečuje povprečno število parcel na kmetijo.

Grafikon 4 : Velikostna struktura kmetij v EU in Sloveniji glede na površino kmetijske zemlje.

Fig. 4: Farm size structure in EU countries and Slovenia (agricultural land)

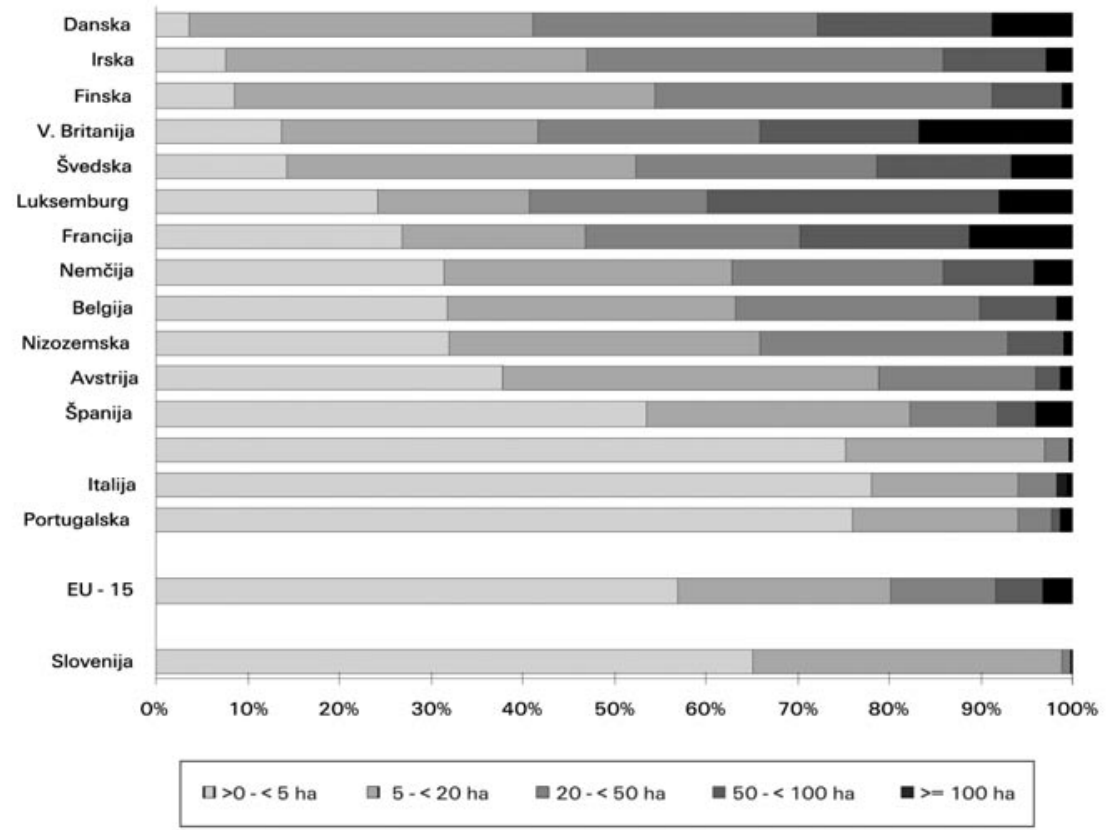

Vir/Source: 
Slika 5 : Struktura kmetij v EU in Sloveniji glede na število kosov kmetijskih zemljišč.

Fig 5: Number of parcels per farm in EU and Slovenia.
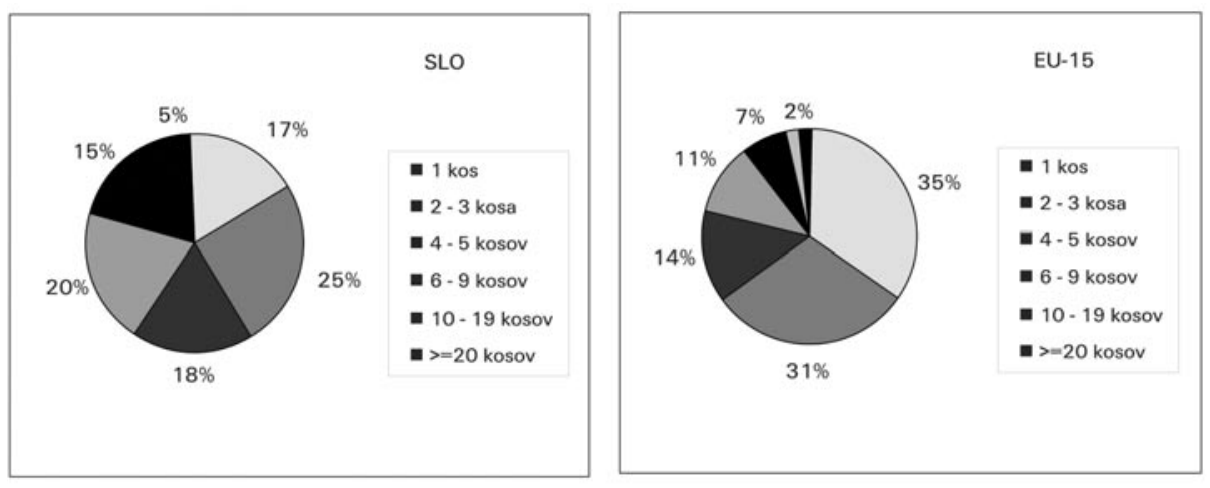

Vir/Source:

\section{Proizvodna struktura kmetij}

Proizvodna struktura slovenskih kmetij je posledica tako strukture rabe kmetijskih zemljišč kot tudi deleža pridelave posameznih poljščin oziroma reje posamezne vrste živine. Kot kaže primerjava proizvodne usmerjenosti kmetij med Slovenijo in EU, je pridelava posameznih poljščin na slovenskih kmetijah veliko bolj razdrobljena, setvena sestava pa dokaj poenostavljena in zožena. Medtem ko je delež kmetij, ki pridelujejo posamezne poljščine, praktično pri vseh izbranih kulturah v Sloveniji večji, pa so povprečne površine povsod manjše. Tako slovenska kmetija $v$ povprečju prideluje osemkrat manj žita, trinajstkrat manj pšenice, štirikrat manj koruze in celo sedemkrat manj krompirja kot primerljiva kmetija v EU. Kljub izraziti travniški naravnanosti slovenskega kmetijstva je celo površina travinja na kmetijo v EU kar petkrat večja kot v Sloveniji. 
Grafikon 6 : Delež kmetij po usmeritvi pridelave in površini posameznih poljščin.

Fig. 6: Farm production orientation.
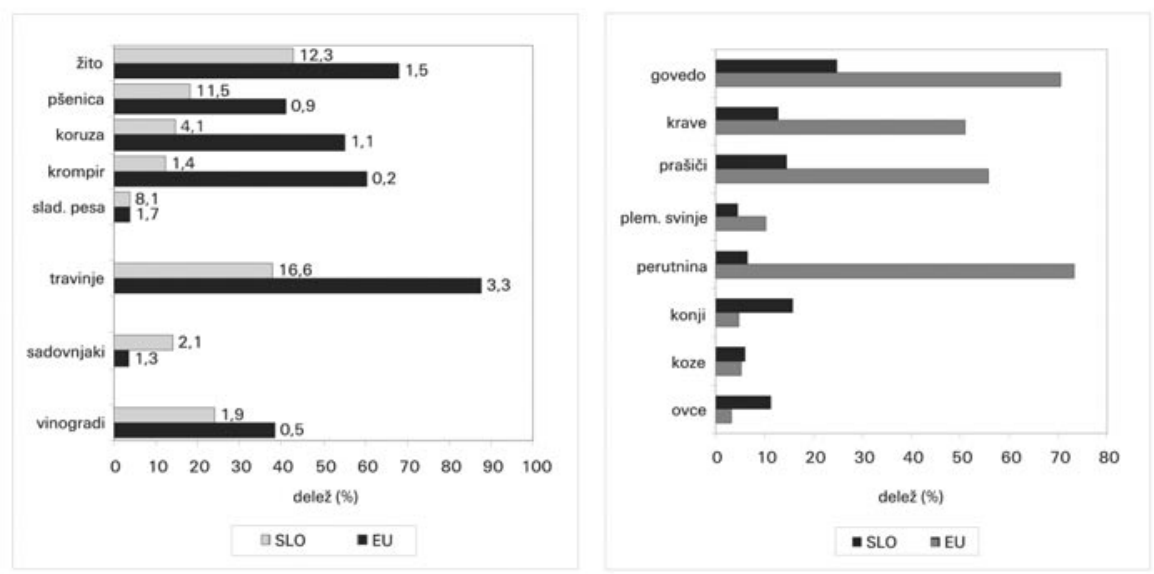

Vir/Source:

Živinorejska usmerjenost slovenskih kmetij je še bolj enostranska kot poljedelska. Govedorejo kot prevladujočo tržno proizvodno usmeritev narekujejo že naravne danosti ter posredno velik delež travinja v strukturi kmetijske zemlje. Pomemben dejavnik pa je brez dvoma tudi velikostna struktura kmetij, ki je primerna predvsem za delovno in dohodkovno intenzivnejše živinorejske proizvodne usmeritve in manj za specializirane poljedelske oziroma poljedelsko živinorejske usmeritve.

\section{Socio-ekonomska struktura kmetij}

Posledice neugodne velikostne strukture kmetij v Sloveniji se kažejo tudi v socioekonomski strukturi. Prevladujejo mešane kmetije, saj so gospodarstva premajhna, da bi lahko zagotovila dohodek samo iz kmetijske dejavnosti. V Sloveniji je le slabih 20 \% čistih kmetij, kar je precej manj kot v državah EU. Majhne kmetije zaradi pogosto neugodnih naravnih razmer večinoma iščejo dohodek v delovno intenzivnih proizvodnih usmeritvah - govedoreji oziroma prireji mleka. 
Slika 7: Struktura delovne sile polnovrednih delovnih moči (PDM) na kmetijah v Sloveniji in EU.

Fig. 7: Labour force structure on farms in Slovenoia and EU.
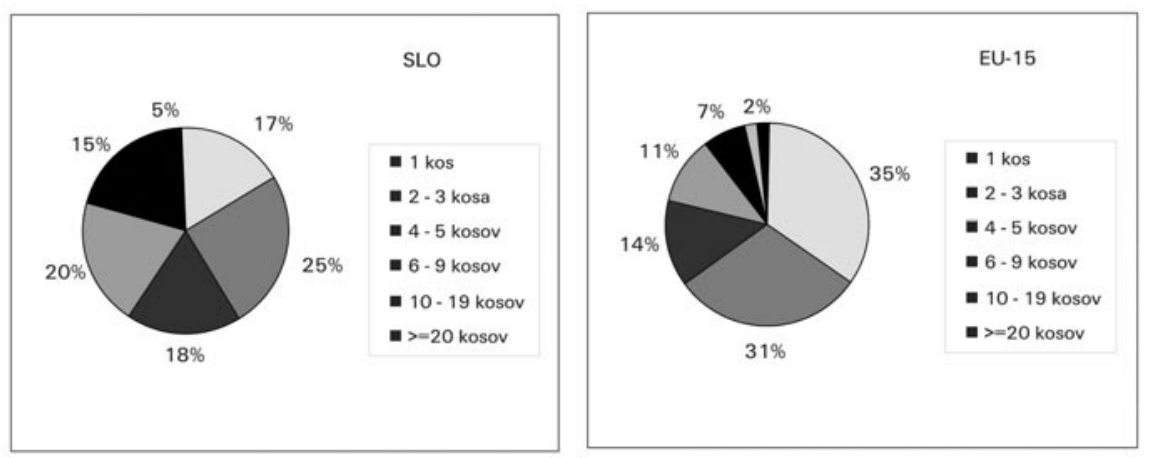

Po podatkih vzorčnega popisa kmetijstva (1997) dela na slovenskih kmetijah okoli 100.000 polnovrednih delovnih moči (PDM). Struktura delovne sile se bistveno razlikuje od podobne strukture $v$ EU. Na slovenskih kmetijah večino dela opravijo ožji člani družinske kmetije, saj zunanjih, redno najetih delavcev, na kmetijah praktično ni. S tem dejstvom povezana relativna nemobilnost delovne sile se odraža tudi $v$ delovni intenzivnosti. V Sloveniji je v povprečju na kmetijo zaposlenih $10 \%$ več delovnih moči kot v povprečju EU, kjer se zaposlenost giblje od 0,7 PDM na kmetijo v Italiji do 1,9 PDM na kmetijo v Veliki Britaniji.

Število PDM na hektar kmetijske zemlje nadalje kaže na nizko splošno storilnost slovenskega kmetijstva. $\mathrm{Na}$ to $\mathrm{v}$ velikem obsegu vplivajo težke pridelovalne razmere, slabša tehnološka opremljenost, slaba strokovna izobraženost pridelovalcev ter predvsem izredno neugodna posestna in zemljiška struktura. $V$ EU je $v$ povprečju zaposlenih več kot štirikrat manj PDM na hektar kot $v$ Sloveniji. Vse države članice EU imajo višjo delovno storilnost v kmetijstvu kot Slovenija. 
Grafikon 8 : Povprečno število PDM na 100 ha kmetijske zemlje v Sloveniji in EU.

Fig. 8: Average number of fully-employed people per 100 ha of agricultur al land.

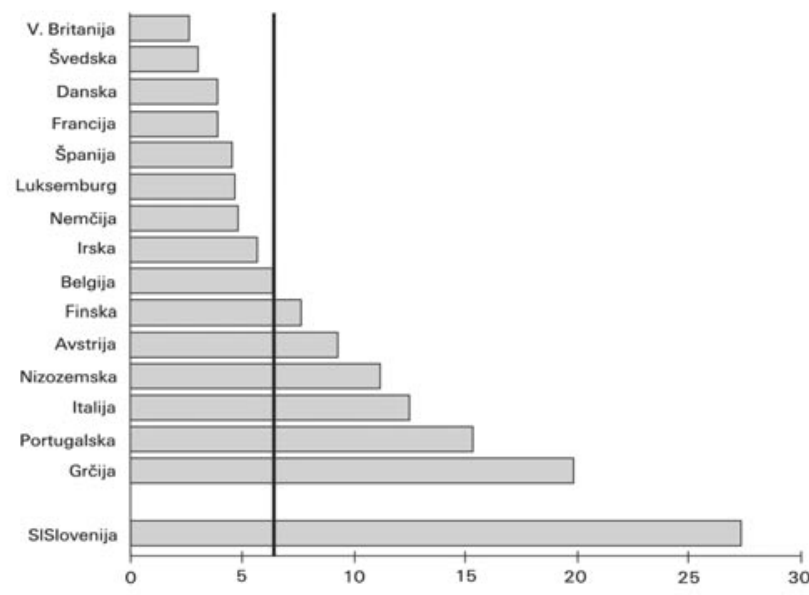

Vir/Source:

\section{Zaključek}

Nezadostni dohodki za polno zaposlitev in s tem neprivlačnost kmetijstva na eni strani ter nemobilnost proizvodnih dejavnikov (predvsem zemlje in delovne sile) so temeljni strukturni problemi slovenskega kmetijstva pred njegovim vstopom v EU. Dvig učinkovitosti in konkurenčnosti kmetijstva je zato temeljna naloga kmetijske strukturne politike, ki pa zahteva tudi izrazitejša in ciljno usmerjena prizadevanja države.

Dejstvo je, da je potrebno razvojno sposobne obrate povečati, izboljšati njihovo storilnost in povečati splošno tržno usmerjenost kmetijstva. Politika ima za to na voljo številne mehanizme - od investicijskih podpor, zemljiške politike do podpor tržnemu organiziranju in prenosu znanja. Gre za vsebinsko in finančno zahtevne premike, s katerimi bi se postopno oblikoval dovolj velik sloj poklicnih kmetij, ki bi bil ne glede na proizvodno usmeritev sposoben preživeti in se razvijati tudi v konkurenčnih razmerah po vstopu $v$ EU. Pri prestrukturiranju kmetij se zastavlja osnovno vprašanje, kako in na kakšen način doseči izboljšanje agrarne strukture kmetij v Sloveniji. Realno dejstvo je, da država nima veliko mehanizmov za učinkovito splošno 
povečevanje kmetij. Možni ukrepi so: ali prevelik poseg v pravno ureditev (omejevanje nakupa zemljišč ali restriktivna davčna politika) ali proračunsko zelo zahtevni ukrepi (rente ali premija ob oddaji zemljišč). Pri tem bi moral z bolj načrtnim delovanjem pomembno vlogo odigrati Sklad kmetijskih zemljišč in gozdov. Kljub proračunski zahtevnosti pa bi svoje mesto $v$ okviru strukturnih podpor morale najti tudi pokojninske rente ali enkratne podpore za tiste, ki bi se svoja kmetijska zemljišča odločili bodisi prodati bodisi oddati v dolgoročni najem.

\section{Summary}

Insufficient income for full-time employment along with lack of attractiveness of agriculture on one hand and immobility of production factors, mainly land and labour force on the other, represent basic structural problems of Slovene agriculture prior to its accession to EU. The increase of efficiency and competitiveness of agriculture are therefore basic objectives of agricultural structural policy which require more pronounced and purposeful efforts made by government.

The fact is that it is necessary to enlarge farms which are capable of development, improve their efficiency and increase general market orientation of agriculture. To meet these requirements the policy has numerous mechanisms at its disposal - from investment supports, land policy to subsidies devoted to market organisation and transfer of knowledge. These are moves demanding as to content and finance which would be required to gradually form a large enough layer of professional farms which would be, regardless of its production specialisation, capable of surviving and developing in competitive conditions after the accession to EU.

At the restructuring of farms a basic question is raised, how and in what way to reach the improvement of agrarian structure of farms in Slovenia. It is true that the government has not many mechanisms for an efficient general enlargement of farms at its disposal. Among possible measures are either: the too intensive intervention into legislation (restriction to land purchase or restrictive tax policy) or very demanding budgetary measures (life annuities or subsidy on land renting). More important role should be played by the Fund of Agricultural Land and Forests. In spite of budget requirements, life annuities or single supports for those who would decide to either sell or rent their land for a longer period should find their place in frame of structural supports. 


\section{Literatura in viri}

Cunder, Tomaž, 2001. Območja z omejenimi dejavniki za kmetijstvo in reforma kmetijske politike v Sloveniji. V: Erjavec, E. (ur.), Juvančič, L. (ur.). Učinki reforme slovenske kmetijske politike. Ljubljana: Društvo agrarnih ekonomistov Slovenije, 2001, str. 83-100. [COBISS-ID 1145960]

Cunder, Tomaž, 2001. Changing of agricultural structures in Slovenia. V: EUErweitugerung : Positionen der Österreichischen und europäischen Landwirtschaft: Sammelband zum 30. internationalen Symposium, veranstaltet von der Bundesanstalt für Agrarwirtschaft und dem Ökosozialen Forum Österreich am 7. und 8. Juni 2000, (Agrarische Rundschau, August 2001). Wien: Ökosoziales Forum Österreich: Bundesanstalt für Agrarwirtschaft, 2001, 2001, str. 65-67.

Cunder, Tomaž, 2000. Economic and agricultural issues for the CEEC linked to the enlargement of the EU. V: Quality and rural development in the mountain regions of the CEEC, Seminar 17 and 18 December 1999, Krakow, Poland, Third thematic seminar: mountain regions as pioneers of sustainable development quality : the comparative advantage of the futur: third preparatory report of the $2^{\text {nd }}$ European Mountain Convention. Krakow: EUROMONTANA, 1997, str. 33-38.

Cunder, Tomaž, 1997. Trends of land use in the Republic of Slovenia. V: PýdnŪ fond ČR a smžry jeho využitŪ : sbornŪk ze seminšÝe vḳze konant'ho ve dnech 13. - 17. ÝŪjna 1997 ve Špindlerovt' mlżnž : proceeding of the seminar RIAE, 13-17 October 1997, Špindlerýv Mlżn, Czech Republic, Praha. VŕZE, 1997, str. 26-34,

Rednak, Miroslav, Erjavec, Emil, Cunder, Tomaž. Ocena posledic ob morebitnem vstopu Slovenije $v$ Evropsko unijo na ekonomski položaj kmetijstva na agregatni ravni $=$ An assessment of the impact of possible Slovene accession into the European Union on the performance of agriculture as a whole. Sodob. kmet., 1996, let. 29, št. 9, str. 365-372. 